\title{
The Impact of Jordan Free Trade Agreements on Trade Flows
}

\author{
Taleb Awad-Warrad, Murad Ahmad Al Tarawneh* \\ Department of Business Economic, Faculty of Business, University of Jordan, Amman, Jordan \\ Email address: \\ t.awad@ju.edu.jo (T. Awad-Warrad), tarawneh.murad@gmail.com (M. A. Al Tarawneh) \\ ${ }^{*}$ Corresponding author
}

\section{To cite this article:}

Taleb Awad-Warrad, Murad Ahmad Al Tarawneh. The Impact of Jordan Free Trade Agreements on Trade Flows. International Journal of Business and Economics Research. Vol. 9, No. 4, 2020, pp. 228-233. doi: 10.11648/j.ijber.20200904.19

Received: June 1, 2020; Accepted: June 15, 2020; Published: July 4, 2020

\begin{abstract}
This study aimed to evaluate the impact of Jordan Free Trade Agreements (FTAs) with 17 Arab countries (Greater Arab Free Trade Area (GAFTA)), United States of America (USA) and European Union (EU) on Jordan trade flows. A Gravity model is used to estimate the impact of FTAs in term of trade creation and trade diversion. The study utilizes a panel data sample coving 125 selected countries trading with Jordan for the period 1997-2017. The study used Feasible Generalized Least Squares (FGLS) to estimate the Gravity model. The study results showed a significant impact of Jordan Gross Domestic Product (GDP), trade partners GDP, Jordan GDP Per Capita (GDPC), trade partners GDPC, distance, common language and border variables on Jordan trade. Further, the differences between Jordan and trade parents GDPs showed an insignificant impact on Jordan trade which implies that most of Jordan trade is among trade partners whom have significant different size of GDP. Furthermore, Jordan - EU agreement showed a significant imports trade creation and exports trade diversion. Jordan - USA agreement showed an imports trade diversion and extra regional exports expansion. Finally, Jordan - GAFTA agreement has a significant import and exports trade creation.
\end{abstract}

Keywords: Impact, Trade Creation, Trade Diversion, Free Trade Agreements, Jordan, Gravity Model, FGLS

\section{Introduction}

Foreign trade plays a key role in obtaining the requirements of production for countries that suffer from limited natural resources, opening an external market for small countries products, achieving the economic development and encouraging investment [1]. Economic and political conditions are the key reasons for countries to form FTAs. Mostly, FTAs formed to eliminate tariffs and some non-tariff barriers [7].

One hundred and twenty four Regional Trade Agreements (RTAs) notified since the adoption of General Agreement on Tariffs and Trade (GATT) in 1947 until end of 1994. The number of FTAs has increased rapidly since the creation of World Trade Organization (WTO) by 1995 . Where by end of 2009, the WTO reported more than 220 FTAs [9].

For a developing country, like Jordan, with a small economy, trade balance deficit and limited natural resources; international trade openness plays a vital role. Bilateral and RTAs can play an important role in improving economic growth, increasing welfare, expanding export market, attracting foreign investment, reducing inputs costs for exports and enhancing competitiveness. The benefits of trade openness has guide decision makers to adopt a strategy of economic integration and trade liberalization at both the international and regional levels [3]. It set the stage for engaging into negotiating with the WTO and ultimately enabled Jordan to gain a WTO membership on April 11, 2000.

The speedily changing of regional and global conditions require Jordan to response promptly. The global situation is becoming more aggressive and the scope of trade is expanding rapidly. Therefore, Jordan FTA direction should follow and support Jordan's international strategy and commitments.

In practical terms, after the FTA had implemented, an assessment of the FTA's actual impact is necessary for determining whether the FTA's objectives have been meet or not. This study seeks to examine the trade creation and trade diversion resulted from applying Jordan FTAs (GAFTA, USA 
and EU) using Gravity model.

This study distinguishes from other studies covered Jordan by the sample size of one hundred and twenty-five countries over a period of 19 years (1997-2017), Adding new variables supporting study requirements. A more detailed analysis conducted by examining the direction and magnitude of trade to assess whether the agreements resulted in a trade creation and/or trade diversion. The main contribution of this study is the following: to the best of our knowledge, no similar attempt has been made to measure trade creation and trade diversion. This is the first study that covers all major FTAs together.

This study includes six parts. First part is the introduction; it gives an overview of the foreign trade importance. Second part, survey the existing literature of the impact of FTAs at international, regional and Jordan levels on trade creation and trade diversion using Gravity model. Third part gives an overview of the Jordan's foreign trade. Fourth Part outlines the research methodology of the study in both qualitative and quantitative analysis. Fifth part includes the study results. Finally, the conclusions and policy implications of the study is presented.

\section{Literature Review}

This section describes previous studies on FTAs impact on trade creation and trade diversion using Gravity model. Over the past 40 years, the gravity equation has been widely used as the main equation to study the ex-post effects of trade agreements. The earlier ex-post studies that used the Gravity model show no clear evidence about the impact of trade agreements in elevating trade $[5,16]$.

Aprilia and Handoyo analyzed the impact of AJECP on Indonesian exports in terms of trade creation and trade diversion. Authors used a panel data for sixteen countries covering the period from 2000-2015. Authors estimate study gravity model using Random Effects Regression (REM). Estimation results showed that there is a significant trade creation caused by AJECP on the Indonesian exports.

The study of Darma and Hasitadi analyzed the effect trade creation and trade diversion occurred due to ASEAN FTAs with (China, Korea and India) on Indonesia foods and beverages exports with members and non-members countries of these FTAs. Authors used a panel data covered twelve countries for the period 2005-2015. Study gravity model augmented by adding dummy variables representing ASEAN-China, ASEAN-Korea and ASEAN-India FTAs.

Sattayanuwat and Tangvitoontham, analyzed the effects of six ASEAN PTAs on ASEAN countries. The study used a panel data of one under and fifty-three countries covering the period from 2007-2011. Study gravity model estimated using PPML. Estimation results showed that ASEAN member countries trade higher in the existence of PTAs. Regional Comprehensive Economic Partnership (RCEP), ACFTA, ASEAN-Japan Comprehensive Economic Partnership (AJCEP) and ASEAN-India FTA (AIFTA) showed intra-blocs trade creation. The study showed that trade diversion resulted of PTAs with higher external tariffs.

The study of Magee [13] estimated the trade effects of Turkey - European Community (EC) customs union using Gravity model. Gravity model estimated using fixed effect passion regression. This study used a data covering Turkey EC trades for the period 1996 -2010. It showed that Turkey EC customs union had an impact on turkey imports. Furthermore, it showed trade creation and trade diversion.

The study of Soufan [15] identified the major factors that affect Jordan exports using the Gravity model covering the period 2003-2012. It used Pooled Estimated Generalized Least Square (EGLS) (Period Seemingly Unrelated Regression (SUR)). It showed that Jordan and trade partners GDP have insignificant on Jordan exports. Moreover, distance, population size and the exchange rate showed a significant impact on Jordan exports.

El-Anis [10] study examined bilateral trade between Jordan and USA before and after the Jordan, USA Free Trade Agreements (JUSFTA) went into force. It showed that trade between Jordan and USA rapidly increased after the implementation of the JUSFTA in 2011. Furthermore, study observed that Jordanian exports to USA have grown more than imports. Therefore, Jordan has benefitted from an overall trade surplus since the implementation of the JUSFTA in comparison to the trade deficit experienced before JUSFTA. In addition, it showed that Jordanian imports from USA now exceed exports and the Jordanian trade deficit may continue in the coming years.

The study of Zidi and Dhifallah [18] aimed to know if the agreements between industrial countries (EU) and developed countries (Tunisia) are able to increase trade between them. Tunisia - EU FTA evaluated using Gravity model. Trade creation and trade diversion variables added to model. It covered Tunisia trades with 41 countries for the period of 1986 - 2010. GLS estimation technique used to estimate study equation. It showed that after five years of the agreement between Tunisia and Europe, there is no trade creation. Further, it showed that the preferential agreement between the two partners does not generate trade diversion of imports. Yet, there is a trade diversion of exports.

Carre're [6] estimated the impact of seven major RTAs using Gravity model. The study used a panel data for 130 countries covering the period 1962 - 1996. Augmented Gravity model presented in the study includes three dummy variables to assess trade creation and diversion impact. The study model estimated using Hausman and Tayolr (HT) estimation technique. The study showed that most of study's RTAs resulted in increasing intra - regional trade (trade creation). As well, trade diversion noticed by a reduction in imports and exports from the rest of the world.

\section{Jordan Foreign Trade}

Jordan has followed an active trade liberalization policy in order to enhance the role of foreign trade sector in the economy [3]. Hence, Jordan signed many FTAs with both Arab and Non-Arab countries. Jordan signed its first FTA 
with a 17 Arab countries (GAFTA); the agreement went into force in 1998. Following the Jordan - GAFTA agreement, Jordan signed its second FTA with USA that went into force in 2001. Furthermore, Jordan signed an FTA covering 28 European Countries (EC); the agreement went into force in 2002. Tables 1 and 2 show a Jordanian imports and exports respectively for the period 1997 and 2017.

Table 1 shows that Jordanian imports from GAFTA, EU and USA FTAs countries made an average of $62 \%$ from Jordan total imports. However, after 2012, Jordan imports from GAFTA, EU and USA FTAs countries decreased to make an average of $55.4 \%$ from Jordanian total imports. Table 2 shows that Jordanian exports to GAFTA, EU and USA FTAs countries made an average of $60 \%$ from Jordanian total exports. Due to region political circumstances after 2011, Jordanian exports to GAFTA, EU and USA decreased.

Figure 1 shows Jordan trade with GAFTA countries during the period 1997-2017. It shows that the gap between Jordan imports and exports increased after signing the agreement due to faster rate of imports and exports increase. Figure 2 shows that the gap between the imports and exports of Jordan trade with EU countries during the period 1997-2017 is the most significant one among all signed FTAs in the study. Jordan's imports from EU countries increased significantly after signing the agreement. Despite that, Jordan's exports to EU countries increased for the first couple of years after signing the agreement, where it became steady after that. Figure 3 shows that after developing the agreement of Jordan - USA import and export trades increased after signing the agreement.



Figure 1. Jordan - GAFTA imports and exports in thousands USD, $1997-$ 2017.

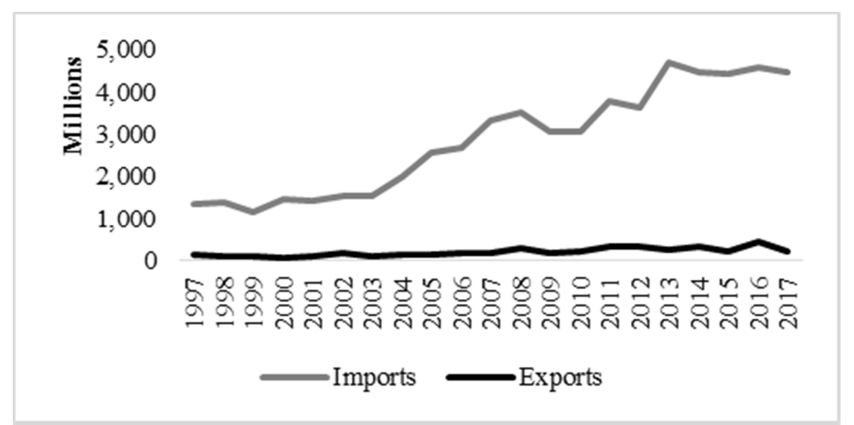

Figure 2. Jordan - EU imports and exports in thousands USD, 1997 - 2017.

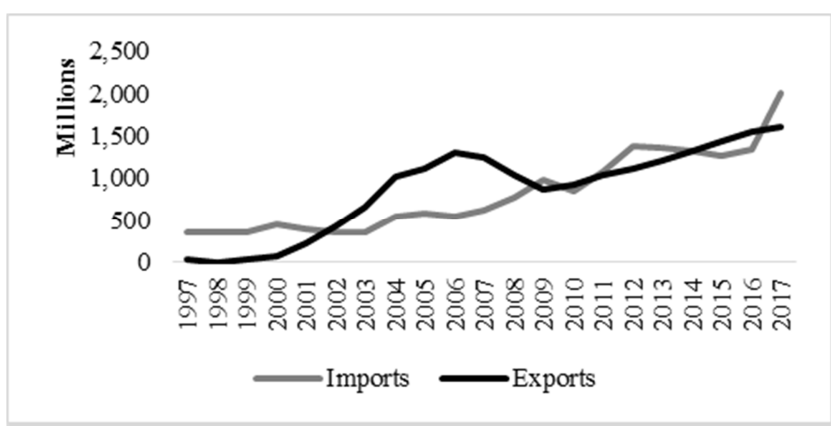

Figure 3. Jordan - USA imports and exports in thousands USD, 1997-2017.

Table 1. Jordanian imports in thousands USD, 1997 - 2017.

\begin{tabular}{lllll}
\hline Year & GAFTA & USA & EU & Other Countries \\
\hline 1997 & 908,295 & 365,830 & $1,348,978$ & $1,315,830$ \\
1998 & 716,308 & 363,991 & $1,387,053$ & $1,497,406$ \\
1999 & 785,954 & 357,654 & $1,185,051$ & $1,348,146$ \\
2000 & $1,075,385$ & 451,648 & $1,459,853$ & $1,552,028$ \\
2001 & $1,146,429$ & 395,946 & $1,448,117$ & $1,880,842$ \\
2002 & $1,268,083$ & 364,314 & $1,546,678$ & $1,840,624$ \\
2003 & $1,570,490$ & 360,955 & $1,534,683$ & $2,187,035$ \\
2004 & $2,486,209$ & 547,609 & $1,997,763$ & $3,112,012$ \\
2005 & $3,504,818$ & 586,483 & $2,575,423$ & $3,787,857$ \\
2006 & $4,091,286$ & 543,574 & $2,697,374$ & $4,114,675$ \\
2007 & $4,536,005$ & 630,069 & $3,338,616$ & $5,026,410$ \\
2008 & $5,592,440$ & 773,726 & $3,531,985$ & $6,973,446$ \\
2009 & $4,423,636$ & 977,117 & $3,056,329$ & $5,618,215$ \\
2010 & $5,297,568$ & 859,625 & $3,049,595$ & $6,055,213$ \\
2011 & $6,788,213$ & $1,077,560$ & $3,768,907$ & $6,666,402$ \\
2012 & $7,255,777$ & $1,384,679$ & $3,629,042$ & $8,464,169$ \\
2013 & $6,430,060$ & $1,361,122$ & $4,687,924$ & $9,117,215$ \\
2014 & $6,800,528$ & $1,319,844$ & $4,481,337$ & $10,186,012$ \\
2015 & $5,131,152$ & $1,260,084$ & $4,426,204$ & $9,708,507$ \\
2016 & $4,270,639$ & $1,341,213$ & $4,582,759$ & $9,048,425$ \\
2017 & $4,646,502$ & $2,000,351$ & $4,460,312$ & $9,333,670$ \\
\hline & & & & \\
\hline
\end{tabular}

Table 2. Jordanian exports in thousands USD, 1997 - 2017.

\begin{tabular}{lllll}
\hline Year & GAFTA & USA & EU & Other Countries \\
\hline 1997 & 669,442 & 32,517 & 145,451 & 743,308 \\
1998 & 513,651 & 7,951 & 111,340 & 754,719 \\
1999 & 612,129 & 41,909 & 116,386 & $1,050,354$ \\
2000 & 645,071 & 66,658 & 79,433 & $1,106,325$ \\
2001 & $1,051,287$ & 234,771 & 98,042 & 910,336 \\
2002 & $1,183,731$ & 431,724 & 203,886 & 950,681 \\
2003 & $1,176,187$ & 662,955 & 115,094 & $1,127,394$ \\
2004 & $1,531,565$ & $1,021,196$ & 136,396 & $1,201,960$ \\
2005 & $1,735,238$ & $1,124,455$ & 156,328 & $1,268,148$ \\
2006 & $2,015,423$ & $1,298,877$ & 170,029 & $1,682,316$ \\
2007 & $2,442,811$ & $1,240,769$ & 181,890 & $1,834,548$ \\
2008 & $3,259,193$ & $1,046,918$ & 308,052 & $3,167,601$ \\
2009 & $3,110,352$ & 872,286 & 169,324 & $2,213,782$ \\
2010 & $3,218,225$ & 928,400 & 237,674 & $2,638,839$ \\
2011 & $3,438,627$ & $1,040,465$ & 344,993 & $3,139,400$ \\
2012 & $3,491,417$ & $1,125,340$ & 335,970 & $2,988,633$ \\
2013 & $3,715,889$ & $1,205,678$ & 271,764 & $2,808,753$ \\
2014 & $3,826,367$ & $1,323,267$ & 344,735 & $2,964,918$ \\
2015 & $3,480,895$ & $1,445,605$ & 223,769 & $2,779,022$ \\
2016 & $3,070,664$ & $1,558,302$ & 435,203 & $2,513,436$ \\
2017 & $2,913,369$ & $1,603,242$ & 239,766 & $2,812,404$ \\
\hline
\end{tabular}




\section{Sample Data and Methodology}

\subsection{Study Sample}

This study used Jordan imports and exports flows covering the period 1997-2017 for one hundred and twenty five countries (panel data). Data extracted from World Bank and Jordanian Department of Statistics (DoS) databases. Countries GDP extracted from World Bank database and missing data extracted from DoS. Distance between Jordan and trading partners extracted from the French Centre d'Etudes Prospectives et d'Informations Internationales (CEPII). A panel data estimation technique used in this study because of its several advantages over both time- series and cross-section data sets; since it has greater degrees of freedom and less multicollinearity that leads to more efficient estimates and giving greater flexibility in modelling differences in behavior across countries which enables to control for unobserved heterogeneity [12].

\subsection{Methodology}

This section describes the econometric model that will be used to evaluate the impact of Jordan FTAs on imports and its resulting impact in term of trade creation and trade diversion using the Gravity model. After an FTA is established, it is important for the policy makers to evaluate its impact; the actual impact of FTA may be quite different from any forecast built based on it. There are two ways to evaluate FTAs. First way, is the pre evaluation way (ex-ante). Second way, is the post evaluation way (ex-post).

This study focused on the ex-post analyses of the FTAs impact on imports. Therefore, Gravity model used for ex-post evaluation; a log-linear Ordinary Least Squares (OLS) regression specification that typically interpreted theoretically as the reduced-form from a formal general equilibrium model [4].

Tinbergen "Shaping the World Economy" introduced the empirical application of Newton's gravity model on international trade. He concluded that a country's income and distance have a statistically significant effect on trade between countries [16]. Since the foundations of Tinbergen study that used the Gravity model to study the international trade, the Gravity model has become a popular model used widely for analyzing the impact of different trade policy issues on bilateral trade flows between different geographical entities.

The basic gravity model of trade, which is analogous to Newton's law of universal gravitation in physics relates the $\left(M_{i j}\right)$ positively to the GDP of the importing country $\left(\mathrm{Y}_{\mathrm{i}}\right)$ and the GDP of the exporting country $\left(Y_{j}\right)$ which means that larger countries would import and export more. $M_{i j}$ is negatively related to the geographical distance between the importing and exporting countries $\left(D_{i j}\right)$ where distance between trades partners used as a proxy of transport costs. Therefore, long distance would increase transport costs and reduce trade flows [11].

$$
M_{i j}=G \frac{Y_{i} Y_{j}}{D_{i j}}
$$

Equation (2) expresses Gravity model in logarithmic form and adding a random error term $\left(u_{i j}\right)$.

$$
\ln M_{i j t}=G+\beta_{1} \ln G D P_{i t}+\beta_{2} \ln G D P_{j t}+\beta_{3} \ln D_{i j}+u_{i j t}
$$

$M_{i j}$ : Country $i$ imports from country $j$.

$G$ : Constant.

$G D P_{i}:$ Jordan GDP.

$G D P_{j}$ : Partner Country GDP.

$D_{i j}$ : Distance between countries capital, or cities with largest population

$\beta$ 's: Unknown coefficients

$$
\begin{gathered}
\ln M_{i j t}=G+\beta_{1} \ln G D P_{i t}+\beta_{2} \ln G D P_{j t}+\beta_{3} \ln D_{i j}+\beta_{4} \ln G D P C_{i}+\beta_{5} \ln G D P C_{j} \\
+\beta_{6} \ln D I F G D P_{i j}+\beta_{7} A D J_{i j}+\beta_{8} L A N G_{i j}+u_{i j t}
\end{gathered}
$$

$A D J_{i j}$ : a binary variable taking the value of 1 if $\mathrm{i}$ and $\mathrm{j}$ have a common land border; 0 otherwise

$L A N G_{i j}$ : a binary variable taking the value 1 if $i$ and $j$ have a common language; 0 otherwise

$G D P C_{i}$ : Country $i$ (Jordan) Gross Domestic Product Per Capita

$G D P C_{j}$ : Country $j$ (trading partners) Gross domestic product per capita

DIFGDP $P_{i j}$ : Difference between country $i$ (Jordan) and country $j$ (trading partners)

To take into consideration the resulting trade creation and trade diversion, three variables for each FTA were added. The first represents trade between Jordan and FTA's trade partners
$\left(M T_{F T A}\right)$; it used to measure trade creation. The second represents Jordan import from Rest of World $(R W)$ countries $\left(M T_{F T A-R W}\right)$; it used to measures import trade diversion. The third, is an indicator variable of Jordan export to RW countries $\left(X T_{F T A-R W}\right)$; it used to measures export trade diversion.

$M T_{F T A}$ : a dummy variable taking value of 1 if importing country $\mathrm{i}$ (Jordan) and exporting country $\mathrm{j}$ (FTA member) on year $\mathrm{t}$; 0 otherwise.

$M T_{F T A-R W}$ : a dummy variable taking value of 1 if importing country $i$ (Jordan) and exporting country $j$ is part of the RW; 0 otherwise.

$X T_{F T A-R W}$ : a dummy variable taking value of 1 if exporting country $i$ (Jordan) and importing country $j$ is 
part of the RW; 0 otherwise.

Therefore, equation (4) represents the final augmented

trade Gravity model that will be used in this study.

$$
\begin{aligned}
\ln M_{i j t}=\beta_{0} & +\beta_{1} \ln G D P_{i t}+\beta_{2} \ln G D P_{j t}+\beta_{3} \ln D_{i j}+\beta_{4} \ln G D P C_{i}+\beta_{5} \ln G D P C_{j}+\beta_{6} \ln D I F G D P_{i j} \\
& +\beta_{7} A D J_{i j}+\beta_{8} L A N G_{i j}+\beta_{9} M T_{F T A}+\beta_{10} M T_{F T A-R W}+\beta_{11} X T_{F T A-R W}+u_{i j t}
\end{aligned}
$$

\section{Empirical Results}

Before estimating the model, the unit root test is used to test the stationarity of all study variables. There are different tests used to test the variables stationarity. This study used Levin, Lin \& Chu unit root test to test the variables stationarity.

Table 3 shows the results of applying the unit root test for the study variables. It shows that all the study variables $\operatorname{Ln}\left(M_{i j}\right), \operatorname{Ln}\left(G D P_{i}\right), \operatorname{Ln}\left(G D P_{j}\right), \operatorname{Ln}\left(G D P C_{i}\right), \operatorname{Ln}\left(G D P C_{j}\right)$ and $\operatorname{Ln}\left(G D P D_{i j}\right)$ are stationary at the level since the probability values for them is less than $5 \%$.

In light of the unit root test results and to avoid the problem of autocorrelation and heterogeneity, the study estimated the model using feasible GLS (FGLS) to assess the impact of Jordanian FTAs. Table 4 presents the estimation results of equation (4) for the period $1997-2017$.

Table 3. Unit Root Test using (Levin, Lin and Chu) test.

\begin{tabular}{llll}
\hline Variable & Statistics Value & Prob. Value & Decision \\
\hline $\operatorname{Ln}\left(M_{i j}\right)$ & -3.96003 & 0.0000 & Stationary \\
$\operatorname{Ln}\left(G D P_{i}\right)$ & -11.0590 & 0.0000 & Stationary \\
$\operatorname{Ln}\left(G D P_{j}\right)$ & -3.70246 & 0.0001 & Stationary \\
$\operatorname{Ln}\left(G D P C_{i}\right)$ & -12.9734 & 0.0000 & Stationary \\
$\operatorname{Ln}\left(G D P C_{j}\right)$ & -3.45702 & 0.0003 & Stationary \\
$\operatorname{Ln}\left(G D P D_{i j}\right)$ & -2.08053 & 0.0187 & Stationary \\
\hline
\end{tabular}

Source: Authors calculations.

Table 4 results show that $\operatorname{Ln}\left(G D P_{i}\right), \operatorname{Ln}\left(G D P_{j}\right), \operatorname{Ln}\left(G D P C_{i}\right)$, $\operatorname{Ln}\left(G D P C_{j}\right)$ and $\operatorname{Ln}\left(\right.$ Dist $\left._{i j}\right)$ are significant variables at better than the control at the $1 \%$. However, $\operatorname{Ln}\left(G D P D_{i j}\right)$ is insignificant factor. The variables that measure common language $L A N G_{i j}$ and common border $A D J_{i j}$ both are significant at better than the control at the $1 \%$.

Jordan and trade partners GDP variables both are significant with elastic response. Their positive signs follow the economic theory. Hence, an increase of Jordan and trade partners GDPs by $1 \%$ resulted in an increase of Jordan imports by $(3.92 \%, 1.71 \%)$, respectively. Furthermore, Jordan GDP per capita is significant and elastic response. Thus, Jordan GDPC variable negative sign means that an increase of Jordan GDPC by $1 \%$ led to decrease of Jordan imports by $7.9 \%$. Jordan GDPC is negative due to the decrease of Jordan GDPC values since the Syrian crisis where Jordan population increased from 7.3 Million in 2010 until reaching 9.8 Million in 2017 [17]. Moreover, trade partners GDP per capita turned out to be a positive significant variable; where an increase of factor by $1 \%$ resulted in an increase of Jordan imports by $0.15 \%$.

As expected by economic theory, distance between Jordan and trade partners shows a negative impact on Jordan imports. An increase of distance between Jordan and trading partners by $1 \%$ resulted in a decrease of Jordan imports by $-1.05 \%$. Both common border and language variables are significant and have a positive sign. The difference between Jordan and trade partners GDPs have positive impact on Jordan imports, an increase of $1 \%$ in the GDP gap means an increase of Jordan trade imports by $0.05 \%$.

According to the results showed in table 4, Jordan - EU agreement shows a pure imports trade creation since $M T_{E U}$ and $M T_{E U-R W}$ both are significant with a positive sign. Further, $M T_{E U}$ positive and $X T_{E U-R W}$ negative signs indicate that $\mathrm{EU}$ agreement has an exports trade diversion impact.

Jordan - USA agreement shows that Jordan witness an extra regional export expansion after signing this agreement. This result built based on the $M T_{U S}$ negative and $X T_{U S-R W}$ signs. An import trade diversion resulted from this agreement due to the negative signs of $M T_{U S}$ and $M T_{U S-R W}$. However, $M T_{U S-R W}$ is an insignificant variable.

In addition, the study shows that GAFTA have an imports trade creation impact since both $M T_{G A F T A}$ and $M T_{G A F T A-R W}$ are significant and positive. Further, GAFTA showed an exports trade creation impact since both $M T_{G A F T A}$ and $X T_{G A F T A-R W}$ are significant.

Table 4. FGLS estimation results, $1997-2017$.

\begin{tabular}{lllll}
\hline Variable & Cofficient & Std. error & t-statistics & Prob. \\
\hline$\beta_{0}$ & -58.30828 & 6.300129 & -9.255093 & 0.0000 \\
$\operatorname{Ln}\left(G D P_{i}\right)$ & 3.922576 & 0.574171 & 6.831723 & 0.0000 \\
$\operatorname{Ln}\left(G D P_{j}\right)$ & 1.669186 & 0.048191 & 34.63687 & 0.0000 \\
$\operatorname{Ln}\left(G D P C_{i}\right)$ & -7.867427 & 0.947552 & -8.302894 & 0.0000 \\
$\operatorname{Ln}\left(G D P C_{j}\right)$ & 0.148350 & 0.035357 & 4.195745 & 0.0000 \\
$\operatorname{Ln}\left(D i S t_{i j}\right)$ & -1.032797 & 0.055881 & -18.48217 & 0.0000 \\
$\operatorname{Ln}\left(G D P D_{i j}\right)$ & 0.054011 & 0.044236 & 1.220976 & 0.2222 \\
$L A N G_{i j}$ & 1.000234 & 0.298181 & 3.354447 & 0.0008 \\
$A D J_{i j}$ & 0.780646 & 0.096177 & 8.116782 & 0.0000 \\
$J_{0 r d a n}-$ Europe & & & & \\
$M T_{E U}$ & 0.568658 & 0.246135 & 2.310349 & 0.0209 \\
$M T_{E U-R W}$ & 1.716786 & 0.410329 & 4.183924 & 0.0000 \\
$X T_{E U-R W}$ & -1.107678 & 0.390760 & -2.834676 & 0.0046 \\
$J_{0 r d a n}-\mathrm{USA}$ & & & & \\
$M T_{U S}$ & -2.975079 & 0.469942 & -6.330733 & 0.0000 \\
$M T_{U S-R W}$ & -0.580021 & 0.464121 & -1.249719 & 0.2115 \\
$X T_{U S-R W}$ & 0.982072 & 0.444083 & 2.211462 & 0.0271 \\
$\mathrm{GAFTA}_{M A}$ & & & & \\
$M T_{G A F T A}$ & 6.871597 & 0.242430 & 28.34467 & 0.0000 \\
$M T_{G A F T A-R W}$ & 8.365163 & 0.272205 & 30.73107 & 0.0000 \\
$X T_{G A F T A-R W}$ & -2.546129 & 0.266001 & -9.571872 & 0.0000 \\
\hline
\end{tabular}

Source: Authors calculations.

\section{Conclusions and Recommendations}

The Jordanian economy suffered from political instability of the region and its trade partners. For a developing country, like 
Jordan, decision makers signed many FTAs to enhance foreign trade sector role in the economy. Therefore, it is important to examine the impact of these FTAs to help policy decision makers in assessing the impact of these agreements on economic efficiency. Thus, the impact of trade creation and trade diversion are estimated using the Gravity model by the method of FGLS. The empirical results of the study showed that Jordan and trade partners GDP/ GDPC, distance, GDP differences, common language and border are found to be significant determinants of the Jordanian foreign trade. As well, the study on Jordan GAFTA and EU FTAs showed a significant impact of import and export trade creation. Jordan - USA agreement showed a significant extra regional export expansion. Therefore, the effects of trade creation and trade diversion implies a positive and significant enhancement to economic efficiency.

The empirical findings support the following recommendations to policy makers: first, to expand current agreement that showed trade creation and signs new one with similar partners. Second, since border have significant and positive impact of Jordan foreign trade; the policy makers should pay more attention to facilitate trade flows with neighboring Arab countries. Finally, the government should support the private production of goods that have potential comparative advantage to encourage exports and induce more balanced foreign trade.

\section{References}

[1] Abu-Lila, Ziad. A Panel Data Analysis of Jordan's Foreign Trade: The Gravity Model Approach. International Journal of Economics and Finance 10, no. (1): 204-212.

[2] A. Aprilia, G. T. \& Handoyo, R. D., 2019. Impact Of Trade Creation And Trade Diversion In ASEAN-Japan Comprehensive Economic Partnership (AJCEP). Journal of Developing Economies 4, no. (2):. 99-108.

[3] Awad, Taleb. "Trad Liberalization Policy and Growth: Is It Working for Jordan?" Regional and Sectoral Economic Studies 12, no. 2 (2012): 161-172.

[4] Baier, Scott L., and Jeffrey H. Bergstrand. "Estimating the effects of free trade agreements on international trade flows using matching econometrics." Journal of International Economics 77 (2009): 63-76.

[5] Bergstrand, J. H. "The gravity equation in international trade: some microeconomic." Review of Economics and Statistics 67, no. 3 (1985): 474-481.
[6] Carre're, Ce' line. "Revisiting the effects of regional trade agreements on trade flows with proper specification of the gravity model." European Economic Review 50, no. 2 (2006): 223-247.

[7] Cooper, William. Free Trade Agreements: Impact on U.S. Trade and Implications for U.S. Trade Policy. Congressional Research Service, 2014.

[8] Darma, W. S. \& Hastiadi, F. F., 2017. Trade Creation and Trade Diversion Effects of the ASEAN-China Free Trade Agreement, ASEAN-Korea Free Trade Agreement, and ASEAN-India Free Trade Agreement Implementation on the Exports of Indonesia's Food and Beverages Industry Products. International Journal of Economics and Financial Issues 7, no. (6): 51-58.

[9] Ekanayake, E. M., Amit Mukherjee, and Bala Veeramacheneni. "Trade Blocks and the Gravity Model: A Study of Economic Integration among Asian Developing Countries." Journal of Economic Integration 25, no. 4 (December 2010): 627-643.

[10] El-Anis, Imad. "A review of trade liberalisation and trade between Jordan and the United States." International Journal of Peace and Development Studies 4, no. 6 (2013): 116-124.

[11] Head, Keith. Gravity for Beginners. 2003. economics.ca/keith/gravity.pdf (accessed February 5, 2003).

[12] Hsiao, Cheng. Analysis of Panel Data. 2nd. Cambridge: Cambridge University Press, 2003.

[13] Magee, Christopher S. P. "Trade creation, trade diversion, and the general equilibrium effects of regional trade agreements: a study of the European Community-Turkey customs union." Rev World Econ 2016, no. 152 (2015): 383-399.

[14] C. Sattayanuwat, W. \& Tangvitoontham, N., 2017. Trade Creation and Trade Diversion of ASEAN's Preferential Trade Agreements. IAFOR Journal of the Social Sciences 3, no. (1): 5-20.

[15] Soufan, Thikraiat. "Factors that Affect Jordan's exports During the Period (2003-2012)." International Journal of Business and Social Science 5, no. 6 (1) (2014): 115-121.

[16] Tinbergen, J. Shaping the World Economy; Suggestions for an International Economic Policy. Books (Jan Tinbergen). New York: Twentieth Century Fund, 1962.

[17] World Bank Data. 2019.

[18] Zidi, Ahmed, and Saïd Miloud Dhifallah. "Trade Creation and Trade Diversion between Tunisia and EU: Analysis by Gravity Model." International Journal of Economics and Finance 5, no. 5 (2013): 131-147. 